\title{
EVALUASI KERAGAAN DAN KUALITAS ARTEMIA PRODUKSI LOKAL DAN IMPOR
}

\author{
Bambang Susanto", Wardoyo', Suko Ismi", Ketut Sugama*', dan Ketut Wahyuadi
} \begin{abstract}
ABSTRAK
Kendala yang dihadapi oleh hatcheri udang maupun ikan saat ini adalah sulitnya mendapatkan kista artemia impor, karena produksi sangat sedikit sehingga sangat langka di pasaran dan harganya sangat mahal (Rp350.000/0,5 kg). Kista artemia sudah dapat dihasilkan dari produksi lokal, akan tetapi kualitasnya masih perlu ditingkatkan. Evaluasi ini bertujuan untuk mengetahui kondisi fisik dan kualitas dari kista artemia lokal dibandingkan dengan kista impor. Kista artemia lokal memiliki ukuran diameter (250-251 mikron) dan nauplius $(0,48 \mathrm{~mm})$ yang sama dengan artemia impor. Persentase penetasan kista artemia lokal (59,28\%) dan kista impor (83,50\%). Perbandingan jantan betina untuk artemia lokal $(37,69 \%: 62,31 \%)$ dan artemia impor $(25,86 \%: 74,14 \%)$. Analisis proksimat menunjukkan bahwa nauplius artemia lokal memiliki kandungan protein 49,74\%, lemak $16,72 \%$, serat $4,05 \%$ dan abu $7,21 \%$. Kandungan asam lemak (EPA) nauplius artemia lokal sebesar $14,422 \%$ dan DHA sebesar $0,035 \%$. Kualitas artemia lokal dinilai cukup baik bila dibandingkan dengan artemia impor
\end{abstract}

ABSTRACT: Evaluation on the performance and quality of locally produced and imported artemia. By: Bambang Susanto, Wardoyo, Suko Ismi, Ketut Sugama, and Ketut Wahyuadi.

The main constraint faced by hatchery operators is the difficulties in obtaining artemia cyst as live diets for fish and shrimp larvae. Its availability in the market is very limited and the price is steadily increasing up to Rp350,000,-10.5 kg. Although artemia cyst has been produced in Indonesia, but its quality has to be improved. The present study aimed to compare the quality of locally produced cyst to imported one, in term of size, hatching rate, growth rate and nutritional content. The result showed that the size of cyst and nauplius of both samples were similar ranging from 250-251 $\mu \mathrm{m}$, while the sizes of nauplius were exactly same $(0.48 \mathrm{~mm})$. Hatching rate of local cyst was $59.28 \%$ while imported cysts of different branch were 39.00 and $83.50 \%$. Sex ratio of the local artemia was $37.69 \% \mathrm{M}: 62.31 \% \mathrm{~F}$ and the imported artemia was $25.86 \% \mathrm{M}: 74.14 \% \mathrm{~F}$. The nutritional value of local artemia nauplius was protein $49.74 \%$; lipid $16.72 \%$; fibre $4.05 \%$ and ash $7.21 \%$. while that of imported one was protein $53.20 \%$; lipid $18.32 \%$; fibre $4.91 \%$ and ash $6.66 \%$. The fatty acid (EPA) content of local nauplius artemia were $14.422 \%$ and DHA were $0.035 \%$. Local cyst containing higher EPA but lower DHA compared to imported cyst.

KEYWORDS: artemia cyst, hatching percentage, sex ratio, proximate, fatty acid

\section{PENDAHULUAN}

Umumnya kista artemia yang selama ini dipergunakan oleh hatcheri untuk pakan benih ikan dan udang semuanya masih berasal dari produk impor. Untuk memenuhi kebutuhan artemia dalam negeri dibutuhkan dana 20 milyar rupiah per tahun (Harefa, 1997). Kista yang beredar di pasaran sampai saat ini terdiri atas berbagai merek dagang yang kualitasnya sangat bervariasi. Hasil uji daya tetas kista artemia impor menunjukkan kisaran yang mencolok yaitu 10\%-90\%, efisiensi penetasan dari setiap gram kista artemia berkisar 65.000-304.000 nauplii (Tomey, 1993). Sementara kista produksi lokal sudah dapat diproduksi di tambak garam Madura (Susanto et al., 1993; Wardoyo et al., 1993; Yunus et al., 1994a), akan tetapi kualitasnya masih perlu ditingkatkan.
Kista artemia produksi lokal umumnya dibudidayakan dengan memanfaatkan tambak garam dan diberi pakan tambahan berupa limbah pertanian. Artemia dapat dibudidayakan baik untuk produksi kista maupun biomassa di tambak, karena artemia merupakan hewan penyaring makanan yang tidak selektif dan dapat memakan bahan apapun yang berukuran kurang dari 50 mikron. Kista yang dihasilkan oleh induk artemia mempunyai komposisi kandungan haematin dalam korion yang berbeda, sehingga akan menentukan perbedaan kondisi fisik dan ketahanan kista dari pengaruh luar (Stappen, 1996). Warna dan ketebalan cangkang kista antara produksi impor dan lokal tergantung dari kondisi di mana induk artemia tersebut dapat hidup. Tujuan dari evaluasi ini adalah untuk mengetahui kondisi fisik dan kualitas kista artemia lokal maupun impor dilihat dari pertumbuhan. sintasan dan nilai nutrisinya.

Peneliti pada Loka Penelitian Perikanan Pantai Gondol 


\section{BAHAN DAN METODE}

Evaluasi keragaan kista artemia dilakukan di laboratorium Lolitkanta Gondol Bali dengan beberapa tahapan

\section{Evaluasi Kondisi Fisik dan Daya Tetas Kista}

Kista artemia yang digunakan dalam evaluasi ini berasal dari produksi lokal dan impor. Kista artemia lokal adalah kista artemia hasil panen dari budi daya di tambak garam Madura, yang proses pengeringan dan pengemasannya dalam kaleng hampa udara dilakukan di Lolitkanta Gondol Bali. Dua macam kista artemia impor sebagai perbandingan berasal dari USA dalam bentuk kemasan kaleng hampa udara. Untuk mengetahui banyaknya butiran kista artemia, maka diambil secara acak kista produk lokal dan impor masing-masing sebanyak satu gram, kemudian direndam dalam air laut selama satu - dua jam dan diaerasi, serta dihitung jumlahnya. Perubahan bentuk kista artemia diamati setelah direndam dalam air laut. Untuk pengujian daya tetas dan efisiensi penetasan diambil masing-masing kista artemia sebanyak dua gram dan dimasukkan dalam wadah gelas ukur volume $1.000 \mathrm{~mL}$. Pengujian daya tetas ini menggunakan rancangan acak lengkap dengan empat kali ulangan. Untuk mengetahui kualitas kista yang mengapung dan tenggelam. pengujian dilakukan dalam air dengan salinitas 0 ppt dan 35 ppt pada perendaman selama satu jam. Kemudian kista artemia tersebut disifon dan dimasukkan dalam bak penetasan selama 48 jam. Penghitungan persentase dan efisiensi penetasan sesuai dengan pendapat Yunus (1994) yaitu persentase penetasan (HP) dihitung sebagai berikut

$$
H P=\frac{N}{N+E}
$$

dengan:

$N=$ Jumlah rata-rata nauplius

$E=$ Jumlah rata-rata embrio yang tidak menetas

Efisiensi penetasan $(\mathrm{HE})=$ Jumlah nauplius yang menetas dari satu gram kista

\section{Evaluasi Pertumbuhan dan Sintasan Artemia}

Wadah yang dipergunakan berupa bak polikarbonat sebanyak sembilan buah, masing-masing diisi air laut sebanyak $30 \mathrm{~L}$. Kepadatan awal nauplius artemia mengacu pada penelitian Yunus (1993) yaitu sebanyak 500 ind./L untuk setiap perlakuan yaitu (A) artemia lokal, (B) artemia impor I, dan (C) artemia impor II. Penelitian menggunakan rancangan acak lengkap dengan tiga ulangan. Selama penelitian, media pemeliharaan dilengkapi dengan sistem aerasi dan setiap hari diberi pakan berupa fitoplankton (Dunnaliella sp. dan Thalassiosira). Parameter yang diamati adalah panjang tubuh, derajat sintasan, rasio kelamin, jumlah kista dalam ovisac, dan ukuran kista yang dihasilkan. Pengamatan pertumbuhan dan sintasan artemia dilakukan selama 25 hari.

\section{Evaluasi Kandungan Nutrisi Nauplius Artemia Lokal dan Impor}

Evaluasi kandungan nutrisi nauplius artemia, dilakukan dengan menetaskan kista artemia lokal maupun impor II sebanyak $100 \mathrm{~g}$ selama 24 jam. Setelah menetas kemudian nauplius artemia tersebut disifon dan dicuci dengan air tawar. Kandungan nutrisi yang diamati adalah protein, lemak, serat, dan abu, sedangkan untuk menganalisis kandungan asam lemak dengan menggunakan alat gas kromatografi.

\section{HASIL DAN BAHASAN}

\section{Kondisi Fisik dan Daya Tetas Kista Artemia}

Kista artemia, baik produk impor maupun lokal dalam kondisi anaerob atau sesaat dibuka dari dalam kaleng hampa udara berbentuk bulat dan cekung seperti bola kempes. Hal ini dikarenakan keadaan embrio dalam masa diapause atau embrio tidak aktif atau dikenal dengan fase cryptobiosis dan setelah direndam sekitar satu jam, bentuk kista artemia menjadi bulat utuh. Kista artemia impor berwarna coklat muda sedangkan kista lokal berwarna coklat tua/gelap. Perbedaan warna pada kista artemia diduga berhubungan dengan kandungan haematin pada korion. Semakin banyak haematin maka kista artemia semakin berwarna coklat gelap, ini menunjukkan bahwa induk artemia yang hidup dalam kondisi air bersalinitas sangat tinggi (120-160 ppt) dan suhu cukup panas $\left(35^{\circ}-39^{\circ} \mathrm{C}\right)$ dan sinar matahari yang sangat cerah memungkinkan induk artemia mensintesis haemoglobin semakin banyak sehingga kandungan haematin dalam kista makin tinggi. Artemia impor biasanya berasal dari induk artemia yang hidup dalam air bersalinitas tinggi (150-170 ppt) akan tetapi suhu air masih di bawah $25^{\circ} \mathrm{C}$, sehingga produksi haemoglobin tidak sebanyak artemia yang hidup di daerah panas, yang menyebabkan warna kista artemia impor coklat pucat. Menurut Stappen (1996), konsentrasi haematin menentukan warna pada cangkang kista artemia yaitu dari warna pucat ke warna coklat gelap, dan kegunaan dari haematin adalah melindungi embrio dari gangguan secara mekanik dan radiasi ultraviolet matahari. Diameter kista artemia impor dan lokal relatif sama yaitu sekitar 250 mikron. Jumlah kista lokal setiap gram sekitar 
190.000-200.000, sedangkan kista impor 200.000250.000. Dari pengujian daya tetas kista artemia diperoleh persentase penetasan seperti pada Tabel 1

Daya tetas kista artemia impor I, menunjukkan nilai yang sangat rendah $(P<0,05)$. Hal ini diduga kista tersebut merupakan stok lama dan telah disimpan dalam suhu kamar, sehingga banyak embrio yang mati. Akan tetapi daya tetas kista lokal lebih rendah daripada kista impor II.

Persentase penetasan kista artemia lokal dan impor ini dihitung pada saat masa penetasan 48 jam (Sorgeloos \& Kulasekarapandian, 1986 dalam Kontara et al. 1987; Stappen, 1996; Harefa, 1997). Pada masa penetasan 24 jam kista impor II banyak yang menetas, akan tetapi kista lokal masih menunjukkan stadia pecah kulit (breaking stage). Kuat kerasnya korion dari kista lokal dimungkinkan sebagai akibat dari tingginya kandungan haematin dalam lapisan alveoler. Kista artemia terdiri atas beberapa lapis yang memiliki ketebalan berbedabeda, berturut-turut dari luar adalah selaput luar $(0,1$ mikron), lapisan kortikel (0,7-1,5 mikron), lapisan alveoler (4-6 mikron), selaput kutikular luar (0,5 mikron), lapisan fibrosa (1,5 mikron), selaput kutikular dalam (0,4 mikron) dan rongga subkutikular $(0.5$ mikron) (Fuad \& Tadjudin, 1985; Mujiman, 1983 Stappen, 1996; Harefa, 1997)

Kista artemia yang tenggelam pada media salinitas 35 ppt menghasilkan persentase penetasan sebesar $68,71 \%$ (lokal) dan $83,35 \%$ (impor) dari seluruh kista yang tenggelam. Sedangkan kista artemia yang tenggelam pada media salinitas 0 ppt menghasilkan persentase penetasan sebesar $75,62 \%$ (lokal) dan $97,20 \%$ (impor). Kista artemia yang mengapung pada media air salinitas 35 ppt masih dapat menetas dan menghasilkan persentase penetasan untuk kista artemia lokal dan impor berturut-turut sebesar 4,41\% dan $2,34 \%$, sedangkan pada salinitas 0 ppt untuk kista artemia impor menetas sebesar 2,58\%. Efisiensi penetasan untuk setiap gram kista impor dan lokal tersaji dalam Tabel 2

Uji perendaman dengan menggunakan air bersalinitas 35 ppt menunjukkan bahwa kista lokal banyak yang tenggelam dan sedikit mengapung sedangkan kista artemia impor sedikit tenggelam dan banyak yang mengapung. Dengan menggunakan air bersalinitas 0 ppt maka kista artemia lokal semua

Tabel 1. Daya tetas kista artemia produk lokal dan impor pada salinitas 35 ppt.

Table 1. Hatching rate of artemia cyst from local and import production at 35 ppt salinity

\begin{tabular}{lrc}
\hline $\begin{array}{c}\text { Kista artemia } \\
\text { Artemia cyst }\end{array}$ & \multicolumn{2}{c}{ Daya tetas (Hatching rate) } \\
\cline { 2 - 3 } & \multicolumn{2}{c}{ 24 jam (hour) } \\
\hline Lokal (Local) & $26.80 \pm 0.89^{b}$ & $59.28 \pm 2.39^{b}$ \\
Impor I (Import /) & $2.05 \pm 0.67^{a}$ & $39.00 \pm 0.99^{a}$ \\
Impor II (Import II) & $75.50 \pm 3.76^{c}$ & $83.50 \pm 3.73^{c}$
\end{tabular}

Angka dalam kolom yang diikuti huruf superskrip sama tidak berbeda nyata (Values in columns with the same superscript are not significantly different) $(P>0.05)$

Tabel 2. Efisiensi penetasan kista artemia lokal dan impor

Table 2. Hatching efficiency of local and imported artemia cyst.

\begin{tabular}{|c|c|c|c|c|}
\hline \multirow{2}{*}{$\begin{array}{l}\text { Salinitas } \\
\text { Salinity }\end{array}$} & \multicolumn{2}{|c|}{$\begin{array}{l}\text { Artemia impor II (Imported artemia II) } \\
\text { (ind.) }\end{array}$} & \multicolumn{2}{|c|}{$\begin{array}{l}\text { Artemia lokal (Local artemia) } \\
\text { (ind.) }\end{array}$} \\
\hline & $\begin{array}{l}\text { di dasar } \\
\text { at the bottom }\end{array}$ & $\begin{array}{l}\text { mengapung } \\
\text { floated }\end{array}$ & $\begin{array}{l}\text { di dasar } \\
\text { at the bottom }\end{array}$ & $\begin{array}{l}\text { mengapung } \\
\text { floated }\end{array}$ \\
\hline $35 \mathrm{ppt}$ & $\begin{array}{c}116.700 \pm 2.67^{a} \\
(83.35 \%)\end{array}$ & $\begin{array}{c}4.670 \pm 370^{a} \\
(2.34 \%)\end{array}$ & $\begin{array}{c}133.300 \pm 2.180^{a} \\
(68.71 \%)\end{array}$ & $\begin{array}{l}8.560 \pm 330 \\
(4.41 \%)\end{array}$ \\
\hline $0 \mathrm{ppt}$ & $\begin{array}{c}194.400 \pm 2.260^{b} \\
(97.20 \%)\end{array}$ & $\begin{array}{l}5.165 \pm 290^{a} \\
(2.58 \%)\end{array}$ & $\begin{array}{l}146.700 \pm 5.320^{b} \\
(75.62 \%)\end{array}$ & 0 \\
\hline
\end{tabular}

Angka dalam kolom yang diikuti huruf superskrip sama tidak berbeda nyata (Values in columns with the same superscript are not significantly different) $(P>0.05)$ 
tenggelam dan kista artemia impor banyak yang tenggelam dan sedikit yang mengapung. Hal ini menunjukkan bahwa kista artemia lokal yang banyak mengandung haematin memiliki bobot yang lebih tinggi dan cangkang kista yang lebih tahan. Dari hasil uji perendaman, kista yang tenggelam dari produksi lokal maupun impor kemudian ditetaskan akan menghasilkan daya tetas yang cukup tinggi.

\section{Pertumbuhan dan Sintasan Artemia Lokal dan Impor}

Pertumbuhan artemia lokal dari instar satu menjadi instar dua dicapai selama 24 jam, sedangkan nauplius artemia impor sekitar 18-20 jam. Menurut Fuad \& Tadjuddin (1985) instar dua dicapai selama 20 jam, sedangkan menurut Mudjiman (1983) instar dua dicapai selama 24 jam. Ukuran nauplius artemia lokal dan impor saat menetas sekitar 0,40-0,48 mm dan ukuran instar dua sekitar 0,6 mm. Djarijah (1995) menyatakan bahwa nauplius artemia baru menetas mempunyau ukuran $0,4 \mathrm{~mm}$ dan instar dua sekitar $0,6 \mathrm{~mm}$. Pertambahan panjang badan artemia yang berasal dari lokal dan impor terlihat pada Gambar 1.

Dari Gambar 1 terlihat bahwa pertumbuhan artemia lokal dan impor sampai hari ke-25 menunjukkan panjang total antara 9,20-10,50 mm, artemia lokal memperlihatkan pertumbuhan yang lebih panjang yaitu $10,50 \mathrm{~mm}$ dibandingkan artemia impor | sekitar 10,28 mm serta artemia impor 11: 9,20 mm. Stappen (1996) berpendapat bahwa artemia dewasa dalam kondisi optimal dapat mencapai panjang sekitar $10 \mathrm{~mm}$. Pada hari ke-5, pertumbuhan yang lebih cepat artemia impor II sekitar $2,50 \mathrm{~mm}$, diikuti artemia lokal 2,28 mm dan artemia impor / sekitar 1,96 mm. Sampai dengan ke-15, artemia lokal tumbuh lebih cepat yaitu menjadi $8,65 \mathrm{~mm}$, disusul artemia impor I yaitu 8,10 $\mathrm{mm}$ dan artemia impor II sekitar $5,80 \mathrm{~mm}$. Induk artemia betina dewasa memperlihatkan tonjolan (ovisac) yang berisi kista. Pengamatan jumlah kista dalam ovisac untuk artemia lokal sebanyak 30-65 butir dengan diameter antara 214-240 mikron. sedangkan artemia impor sekitar 68 butir dengan diameter kista sekitar 228-240 mikron.

Artemia lokal dan artemia impor pada akhir pengamatan menunjukkan persentase sintasan berkisar antara 41\%-53\%. Rendahnya sintasan dari artemia lokal maupun artemia impor diduga karena dalam media kultur terdapat kotoran dari artemia yang ikut teraduk aerasi dan akhirnya termakan oleh artemia Dengan sifat yang dimiliki artemia yaitu tidak selektif terhadap makanan apapun (Kontara et al., 1987 Yunus, 1993), kotoran yang termakan dimungkinkan akan menyebabkan racun sehingga artemia banyak yang mati. Selain itu juga wadah yang digunakan berupa bak polikarbonat yang transparan sehingga artemia banyak terkumpul pada satu bagian yang sangat terang, karena artemia bersifat fototaksis, hal ini menyebabkan artemia saling bertumpukan dan banyak yang mati. Artemia lokal dan impor terlihat pada Gambar 2

Dari Gambar 2 terlihat bahwa sintasan artemia lokal (45\%) masih lebih baik dari artemia impor I yaitu $(41 \%)$, akan tetapi lebih rendah dibandingkan dengan artemia impor II (53\%)

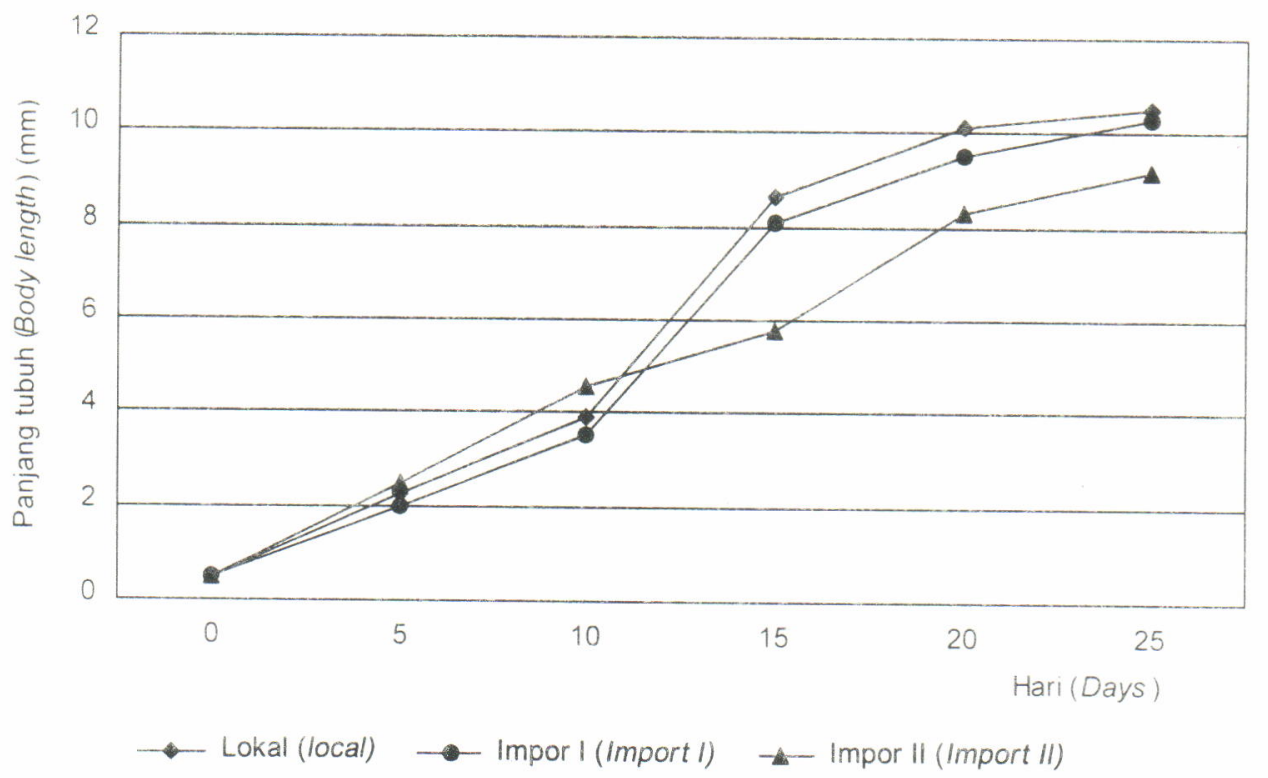

Gambar 1. Panjang badan artemia lokal dan impor selama penelitian. Figure 1. Body length of local and import artemia during experiment 


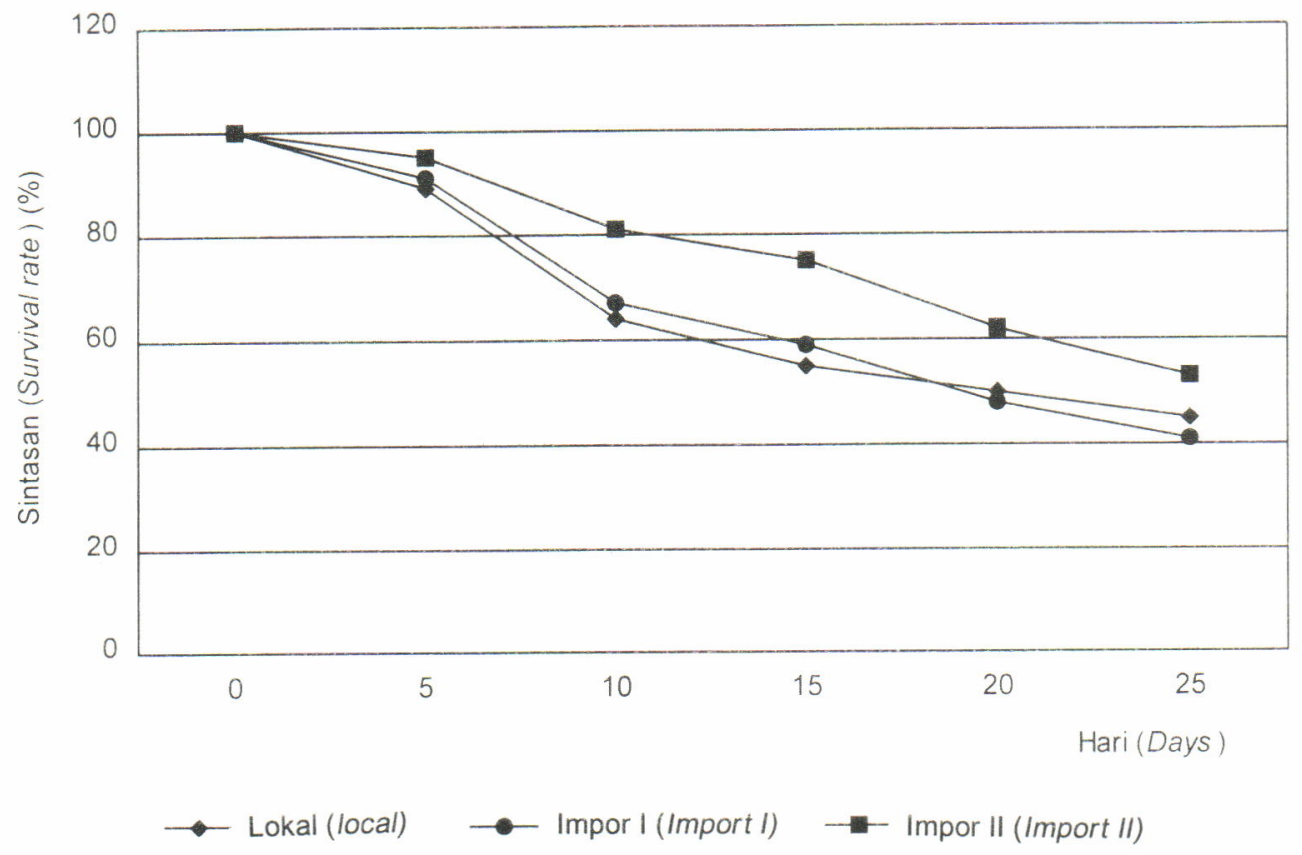

Gambar 2. Sintasan artemia lokal dan impor.

Figure 2. Survival rate of local and imported artemia

Sebagai data penunjang dilakukan pengukuran peubah kualitas air yang menunjukkan kisaran yang masih layak dan masih dalam batas toleransi untuk kehidupan artemia. Suhu air berkisar antara $27,8^{\circ}-$ $32,5^{\circ} \mathrm{C}, \mathrm{pH} 8,08-8,39$, intensitas cahaya $2.750-5.760$ lux, oksigen $3-5 \mathrm{mg} / \mathrm{L}$, dan salinitas $35 \mathrm{ppt}$.

Pada pengamatan hari ke-15 terlihat jelas perbedaan antara artemia jantan dan artemia betina yaitu pada pangkal kepala dan bagian perutnya. Artemia jantan pada kepalanya terdapat semacam penjepit (graspers), sedangkan pada artemia betina terlihat adanya tonjolan semacam perut yang berisi bulatan hitam, tonjolan tersebut dinamakan ovisac. Perbandingan jenis kelamin atau sex ratio dari artemia lokal dan impor tertera pada Gambar 3.

Perbandingan jantan betina artemia lokal menunjukkan perbandingan yang cukup baik karena persentase jantan lebih banyak (37,69\%) sehingga dapat melakukan perkawinan lebih efektif, sedangkan persentase betina sebesar $62,31 \%$. Artemia impor I dan II memiliki perbandingan jantan betina sekitar $28,14 \%: 71,86 \%$ dan $25,86 \%: 74,14 \%$ (Gambar 3 ). Banyaknya artemia betina dalam media kultur akan menentukan banyaknya kista yang dihasilkan, akan tetapi perbandingan jumlah artemia jantan dan betina yang seimbang sangat menentukan fertilitas kista yang dihasilkan

\section{Kandungan Nutrisi Nauplius Artemia Lokal dan Impor}

Kandungan nutrisi dari nauplius artemia lokal dan impor yang meliputi protein, lemak, serat, abu, dan kandungan asam lemak disajikan pada Tabel 3 dan Tabel 4

Dari hasil analisis proksimat terlihat bahwa kualitas nauplius artemia lokal masin tergolong baik. Menurut Harefa (1997), bahwa nauplius artemia berkualitas baik memiliki kandungan protein $40 \%$ $60 \%$, lemak $15 \%-20 \%$, abu $3 \%-4 \%$, dan karbohidrat 15\%-20\%. Menurut Yunus et al. (1994b) bahwa nauplius artemia lokal yang dihasilkan dari tambak garam Madura dengan penambahan pakan mengandung protein $58,20 \%-58,60 \%$; lemak $7,92 \%-9,26 \%$; abu $11,14 \%-12,27 \%$; serat $1,16 \%-6,30 \%$, dan kadar air antara $9,06 \%-11,26 \%$

Tabel 4 menunjukkan bahwa nilai kandungan asam lemak dari produk lokal dan impor berbeda. terutama pada asam lemak yang termasuk HUFA $(20: 5(1)-3)$ dan DHA (22:5(1)-3). Hal ini diduga sumber pakan yang digunakan oleh artemia lokal berasal dari campuran pakan tambahan dan plankton yang tumbuh pada budi daya di tambak, sedang artemia impor hanya mengandalkan pakan alami yang tumbuh di media tempat hidup artemia tersebut. 


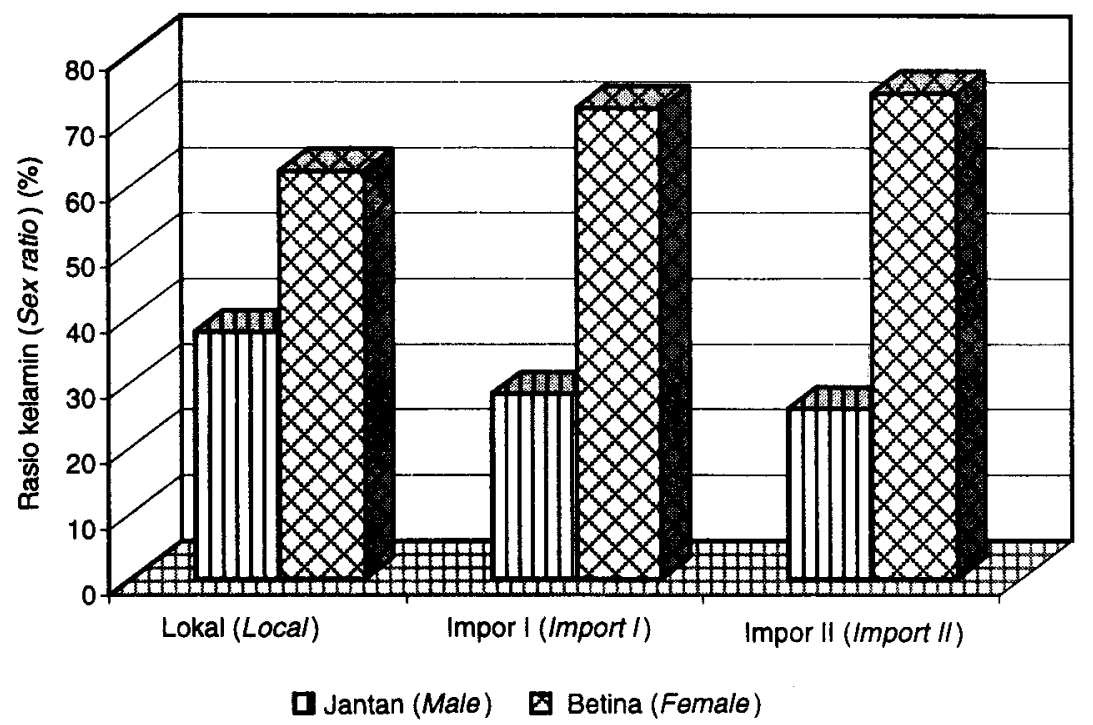

Gambar 3. Perbandingan jantan betina artemia lokal dan impor. Figure 3. Sex ratio of local and imported artemia.

Tabel 3. Analisis proksimat nauplius artemia produksi lokal dan impor. Table 3. Proximate analysis of artemia nauplius of local and imported production.

\begin{tabular}{lccccc}
\hline \multirow{2}{*}{ Nauplius artemia } & Protein & $\begin{array}{c}\text { Lemak } \\
\text { Lipid }\end{array}$ & $\begin{array}{c}\text { Serat } \\
\text { Fibre }\end{array}$ & $\begin{array}{c}\text { Abu } \\
\text { Ash }\end{array}$ & $\begin{array}{c}\text { Kadar air } \\
\text { Moisture }\end{array}$ \\
\cline { 2 - 6 } & $(\%)$ & $(\%)$ & $(\%)$ & $(\%)$ & $(\%)$ \\
\hline Lokal (Local) & 49.74 & 16.72 & 4.05 & 7.21 & 21.48 \\
Impor II (Imported II) & 53.20 & 18.32 & 4.91 & 6.66 & 15.15 \\
\hline
\end{tabular}

Tabel 4. Kandungan asam lemak nauplius artemia produksi lokal dan impor. Table 4. Fatty acid content of nauplius artemia of local and imported production.

\begin{tabular}{ccc}
\hline $\begin{array}{c}\text { Asam lemak } \\
\text { Fatty acid }\end{array}$ & $\begin{array}{c}\text { Lokal (Local) } \\
(\%)\end{array}$ & $\begin{array}{c}\text { Impor (Imported) } \\
(\%)\end{array}$ \\
\hline $14: 0$ & 1.072 & 0.320 \\
$16: 0$ & 27.486 & 13.426 \\
$18: 1$ & 49.410 & 41.975 \\
$18: 3(1) 3$ & 2.394 & 38.844 \\
$20: 3(1) 3$ & 4.957 & 1.243 \\
$20: 5(1) 3$ & 14.422 & 3.172 \\
$22: 1(1) 9$ & 0.227 & 0.012 \\
$22: 5(1) 3$ & 0 & 0.998 \\
$22: 6(1) 3$ & 0.035 & 0 \\
\hline
\end{tabular}

Kandungan asam lemak 20:5(1)-3 dari nauplius artemia lokal memiliki nilai yang sangat tinggi $(14,422 \%)$ bila dibandingkan dengan nauplius impor
$(3,172 \%)$ (Tabel 4). Menurut Watanabe (1978) asam lemak yang termasuk HUFA (20:5(1)-3) sangat efektif untuk ikan dan merupakan sumber asam lemak 
esensial yang dibutuhkan oleh udang. Sementara Kanazawa (1993) menyatakan bahwa ikan laut tidak mampu mensintesis asam lemak (1)-3 rantai 20 dan 22 (EPA dan DHA), karena itu asam lemak tersebut harus ditambahkan dalam pakan. Sedangkan Yunus et al. (1994b) melaporkan hasil analisis asam lemak dari nauplius artemia lokal yang ditambah pemberian pakan adalah $20: 1(1)-9=5,180 \% ; 20: 2(1)-6=2,475 \%$; $20: 5(1)-3=2,691 \%$; dan $22: 6(1)-3=1,770 \%$.

\section{KESIMPULAN DAN SARAN}

\section{Kesimpulan}

Keragaan kista artemia lokal menunjukkan ukuran diameter yang hampir sama dengan impor, warna lebih coklat dan menghasilkan daya tetas yang cukup baik $(59,28 \%)$. Kandungan nutrisi nauplius artemia lokal memiliki kualitas yang dinilai relatif lebih baik bila dibandingkan dengan artemia impor.

\section{Saran}

Untuk menggunakan kista artemia lokal sebagai pakan benih ikan/udang disarankan memakai dekapsulasi agar dapat meningkatkan daya tetas kista artemia lokal tersebut atau dengan proses penetasan selama 48 jam supaya diperoleh persentase penetasan yang tinggi.

\section{DAFTAR PUSTAKA}

Djarijah A.S. 1995. Pakan Ikan Alami. Penerbit Kanisius. Yogyakarta. 46-49.

Fuad, C. dan Daulay, T. 1985. Artemia salina, Kegunaan. Biologi dan Kulturnya. Jaringan Informasi Perikanan Indonesia. Dirjen Perikanan. Jakarta. 1-26.

Harefa, F. 1997. Pembudidayaan Artemia untuk Pakan Udang dan Ikan. Penebar Swadaya, Jakarta. 76 pp.

Kanazawa, A. 1993. Importance of DHA in organism. 357 372. Prosiding Simposium Perikanan Indonesia I. Pusat Penelitian dan Pengembangan Perikanan. Jakarta.
Kontara, K.E., Sumeru, B.S., Ranoemihardjo, dan Mintardjo. 1987. Teknik Budidaya Artemia. Jaringan Informasi Perikanan Indonesia. Dirjen Perikanan. Jakarta. 1-70.

Mudjiman A. 1983. Laporan Hasil Latihan Budidaya Artemia. Dinas Perikanan Jawa Timur, Surabaya. 135 pp.

Sorgeloos, P., Lavens, P., Leger, P., Tackaert, W., and Versichele, D. 1986. Manual for The Culture and Use of Brine Shrimp Artemia in Aquaculture. Faculty of Aqriculture. State University of Ghent. Belgium. 1-319.

Stappen, G.V. 1996. Manual on The Production and Use of Live Food for Aquaculture. Laboratorium of aquaculture and artemia reference center University of Gent. Belgium. 101-318.

Susanto, B., Yunus, Ahmad, T., dan Wahyuadi, K. 1993 Ujicoba pemanfaatan bungkil kelapa untuk menghasilkan kista dan biomas artemia di tambak. J. Penelit. Budidaya Pantai. 9(1):9-22

Tomey, W.A. 1993. Misteri Pembuatan Kapsul Artemia sebagai Sumber Makanan Laut Peternak Ikan Hias secara Komersial. Badan Pengembangan Ekspor Nasional, Departemen Perdagangan. Jakarta.

Watanabe, T. 1978. Nutritional quality feed used seed production of fish. In: Proceeding of $7^{\text {th }}$ Japan-Sovict Joint Symp Aquaculture. Tokyo.

Wardoyo, Susanto, B., Yunus, Sugama, K., dan Darmansyah. 1993. Pemanfaatan beberapa pupuk organik dalam budidaya artemia di tambak Pejarakan, Bali. Prosiding Seminar Hasil Penelitian Perikanan Budidaya Pantai Maros. 135-139.

Yunus. 1993. Penggunaan bungkil kedelai dengan dosis pemberian yang berbeda dalam budidaya artemia pada skala laboratorium. J. Penelit. Budidaya Pantai. $9(1): 1-8$

Yunus. 1994. Kualitas kista artemia produksi domestik. J. Penelit. Budidaya Pantai. 10(5):27-34

Yunus, Ahmad, T., dan Wahyuadi, K. 1994a. Pengembangan substitusi bungkil kelapa untuk meningkatkan produksi kista artemia. J. Penelit. Budidaya Pantai. 10(1):65-76

Yunus, Wardoyo, dan Ahmad, T. 1994b. Kualitas nauplius hasil pemupukan berbeda dan teknik pengeringan kista artemia. J. Penelit. Budidaya Pantai. 10(1):77-83. 


\title{
PENGARUH KADAR KITIN DALAM PAKAN TERHADAP LAJU PERTUMBUHAN DAN KONSUMSI PAKAN HARIAN IKAN GURAMI Osphronemus gouramy LAC.
}

\author{
Anik M. Hariati', Hartati Kartikaningsih"), Dewa Gede Raka Wiadnya' \\ Yanti Suryanti"', dan Subagyo")
}

\begin{abstract}
ABSTRAK
Kitin merupakan suatu polimer rantai panjang dari N-asetil-D-glukosamin. Sumber pakan yang mengandung glukosamin dapat berfungsi sebagai pemacu pertumbuhan dan dapat meningkatkan daya cerna. Tujuan percobaan ini adalah untuk menghasilkan formulasi pakan yang difortifikasi kitin dari limbah pengolahan udang untuk memacu pertumbuhan ikan gurami. Benih ikan gurami yang digunakan ukuran $2,4 \pm 0,02 \mathrm{~g}$ ditebar dalam akuarium ukuran $100 \mathrm{~L}$ dengan kepadatan 50 ekor/akuarium. Perlakuan yang digunakan adalah perbedaan kadar kitin yang ditambahkan pada pakan yaitu $0 \% ; 4 \% ; 8 \% ; 12 \%$; dan $16 \%$. Setiap perlakuan terdiri atas tiga ulangan. Pemberian pakan sebesar $3 \%$ bobot ikan per hari dengan frekuensi dua kali per hari selama 30 hari. Pemberian kitin lebih dari $8 \%$ sudah tidak berpengaruh pada pertumbuhan harian ikan gurami. Penambahan kitin $8 \%$ ke dalam pakan dapat menghasilkan respon pertumbuhan dan pemanfaatan pakan lebih tinggi.
\end{abstract}

ABSTRACT: Effect of chitin in feed on the growth rate and daily feed consumption of gouramy. By: Anik M. Hariati, H. Kartikaningsih, Dewa Gede Raka Wiadnya, Yanti Suryanti, and Subagyo.

Chitin is a long chain polymer of N-Acetil-D-glocosamine. Feed source containing glucosamine may have a function as a growth stimulant and may increase the digestibility. The aim of this study was to produce formulation of feed fortified with chitin from shrimp processing waste to enhauce the growth of gouramy. Gouramy seed of $2.4 \mathrm{~g}$ were stocked in a $100 \mathrm{~L}$ aquarium with of density 50 fish/aquarium. Treatments of different chitin levels added to the feed were $0 \% ; 4 \% ; 8 \% ; 12 \%$; and $16 \%$. The experiment was carried out in three replications. Feed was given daily at $3 \%$ of biomass weight, twice a day for 30 days. The results showed that the chitin added at the level of higher than $8 \%$ had no significant effect on daily growth of gouramy. The $8 \%$ chitin in feed resulted in high growth response and higher feed efficiency.

KEYWORDS: chitin, gouramy, feed, growth rate.

\section{PENDAHULUAN}

Kulit udang mengandung senyawa kimia yang disebut kitin, yang merupakan salah satu jenis polimer alami (biopolimer) terbanyak ke dua setelah selulosa (Knorr, 1984). Meskipun sumber kitin di alam bermacam-macam, namum sampai saat ini sumber utama yang mudah diusahakan adalah cangkang udang-udangan yang secara ekonomis potensial seperti udang dan lobster. Keberadaan kitin dapat menunjang sejumlah besar bentuk kehidupan dari insekta, jamur, dan krustase. Dalam cangkang udang, kitin berikatan dengan protein, garam-garam anorganik seperti kalsium karbonat dan lipid termasuk pigmen-pigmen.

Sumber pakan yang mengandung glukosamin (polimer glukosa dan kitin) dapat berfungsi sebagai pemacu pertumbuhan pada udang. Hal ini terjadi terutama karena percepatan pertumbuhan dan metabolisme karbohidrat pada udang (Kanazawa et al., 1970; Kitabayashi et al., 1971; Clark et al., 1993 dan Fox, 1993). Selanjutnya Clark et al. (1993) menambahkan bahwa kitin antara 1\%-4\% pada sumber pakan akan meningkatkan daya cerna dan pertumbuhan udang. Hal ini memberikan indikas tentang kemampuan udang untuk menyerap dan menggunakan sumber pakan dari glukosamin Secara analog, glukosamin dari sumber kitin diharapkan juga mampu memacu pertumbuhan jenis organisme akuatik lainnya, termasuk ikan gurami (Osphronemus gouramy Lac)

Tujuan percobaan ini adalah untuk mengetahui formulasi pakan dan kadar kitin dalam pakan yang dapat memacu pertumbuhan ikan gurami.

Fakultas Perikanan. UNIBRAW

Peneliti pada Balai Penelitian Perikanan Air Tawar 


\section{BAHAN DAN METODE}

Sebelum pelaksanaan percobaan benih ikan gurami dilatih terhadap pakan yang akan diuji coba dalam akuarium selama satu minggu.

Benih ikan gurami berukuran $2,4 \pm 0,02 \mathrm{~g}$ ditebar dalam akuarium ukuran $100 \mathrm{~L}$ dengan kepadatan 50 ekor/akuarium. Perlakuan yang digunakan adalah perbedaan kadar kitin yang ditambahkan pada pakan, yaitu perlakuan $A=0 \% ; B=4 \% ; C=8 \% ; D=$ $12 \%$, dan $E=16 \%$. Setiap perlakuan terdiri atas tiga ulangan. Pemberian pakan sebesar $3 \%$ bobot biomassa ikan per hari dengan frekuensi pemberian tiga kali per hari Sebelum digunakan pakan uji dianalisis di laboratorium. Pada sore hari dilakukan koleksi sisa pakan pada setiap akuarium. Jumlah pakan yang tersisa (bobot kering) dalam akuarium secara tidak langsung menunjukkan tingkat konsumsi ikan terhadap pakan yang diberikan. Untuk mengetahui pertumbuhan ikan dilakukan penimbangan total ikan setiap 10 hari sekali dan penyesuaian jumlah pakan yang diberikan sesuai dengan pertambahan bobotnya. Bersama dengan itu dilakukan monitoring parameter kualitas air pada pagi hari pukul 07.00 yang meliputi suhu, DO, dan $\mathrm{pH}$. Percobaan ini dilaksanakan selama 30 hari.
Bahan dan komposisi pakan yang digunakan disajikan pada Tabel 1.

Analisis statistik hasil percobaan dilakukan dengan analisis ragam (Snedecor \& Cohran, 1991) Untuk mengetahui signifikasi dari perlakuan digunakan metode LSD pada taraf $5 \%$. Pengujian hubungan antara dosis kitin dalam pakan terhadap variabel yang diukur dilakukan dengan analisis regresi berdasarkan Snedecor \& Cohran (1991).

Parameter yang diukur

a. Laju pertumbuhan harian (SGR)

$$
S G R=\frac{\ln W_{t}-\ln W_{0}}{t} \times 100 \%
$$

b. Laju konsumsi pakan (R)

$$
R=\frac{F R}{B W g} \times 100 \%
$$

c. Konversi pakan (FCR)

$$
F C R=\frac{F}{W_{t}-W_{o}}
$$

\begin{tabular}{|c|c|c|c|c|c|}
\hline \multirow{2}{*}{$\begin{array}{l}\text { Bahan baku } \\
\text { Ingredient }\end{array}$} & \multicolumn{5}{|c|}{ Pakan (Diet) } \\
\hline & A & $\bar{B}$ & C & $\bar{D}$ & $\bar{E}$ \\
\hline Khitin (Chitin) & - & 4.0 & 8.0 & 12.0 & 16.0 \\
\hline Polietilen glikol (Polyethylene glycol) & 16.0 & 12.0 & 80 & 4.0 & \\
\hline Tepung ikan (Fish meal) & 32.0 & 32.0 & 32.0 & 32.0 & 32.0 \\
\hline Tepung kedelai (Soybean meal) & 31.0 & 31.0 & 31.0 & 31.0 & 31.0 \\
\hline Tepung darah (Blood meal) & 3.0 & 3.0 & 3.0 & 3.0 & 3.0 \\
\hline Tepung ubi kayu (Cassava meal) & 10.0 & 10.0 & 10.0 & 10.0 & 10.0 \\
\hline Minyak nabati (Vegetable oil) & 5.0 & 5.0 & 8.0 & 5.0 & 5.0 \\
\hline Vitamin premix (Vitamine $m i x)^{\star}$ & 1.5 & 1.5 & 1.5 & 1.5 & 1.5 \\
\hline $\mathrm{CMC}$ & 1.5 & 1.5 & 1.5 & 1.5 & 1.5 \\
\hline Total & 100.0 & 100.0 & 103.0 & 100.0 & 100.0 \\
\hline \multicolumn{6}{|l|}{ Komposisi (Composition) (\%) } \\
\hline Protein (Crude protein) & 35.0 & 35.0 & 35.0 & 35.0 & 35.0 \\
\hline Lemak (Fat) & 12.0 & 12.0 & 12.0 & 12.0 & 12.0 \\
\hline Energi (Energy) Kkal $/ \mathrm{kg}$ & 3.5 & 3.5 & 3.5 & 3.5 & 3.5 \\
\hline Karbohidrat (Carbohydrate) ${ }^{\star *}$ & 41.0 & 41.0 & 41.0 & 41.0 & 41.0 \\
\hline Abu (Ash) & 12.0 & 12.0 & 12.0 & 12.0 & 12.0 \\
\hline
\end{tabular}

Tabel 1. Formulasi dan komposisi pakan uji

Table 1. Formulation and compotition of tested diets.

* berdasarkan (based on) NRC (1983)

** karbohidrat $=100-($ protein+lemak+abu $) ;$ carbohydrate $=100-($ protein+fat+ash $)$ 
$\mathrm{W}_{0} \quad=$ Rata-rata bobot individu awal

W. = Rata-rata bobot individu thari

$\mathrm{FR} \quad=$ Feeding rate

$\mathrm{BWg}=$ Geometrik body weight

$\mathrm{F} \quad=$ Estimasi konsumsi pakan per individu selama 30 hari

\section{HASIL DAN BAHASAN}

Secara umum parameter kualitas air yang diukur selama penelitian berada pada kisaran baik untuk kehidupan ikan gurami. Suhu air berkisar antara $25,5^{\circ}-26,2^{\circ} \mathrm{C}$, oksigen terlarut $>3,5 \mathrm{mg} / \mathrm{L}$ dan $\mathrm{pH}$ berkisar 7,0-7,3

Hasil analisis ragam terhadap laju pertumbuhan harian menunjukkan bahwa pakan tanpa sumber kitin dan kandungan kitin 4\% menghasilkan pertumbuhan harian tidak berbeda nyata $(P>0,05)$. Sedangkan terhadap pemberian pakan dengan kandungan kitin
$8 \%-16 \%$ berbeda nyata $(P<0,05)$ dalam hal pertumbuhan ikan gurami (Tabel 2). Hal ini menunjukkan bahwa kitin cukup berperan dalam metabolisme karbohidrat pada tubuh ikan gurami.

Konsumsi pakan tanpa sumber kitin, paling tinggi 2,41 (Tabel 3), dan antara perlakuan A dan B tidak menunjukkan perbedaan $(P>0,05)$. Pada perlakuan $C$ dan $D$ laju konsumsi pakan menurun dan berbeda $(P<0,05)$ dengan perlakuan A dan B. Laju konsumsi terendah diperoleh pada pemberian kitin 16\% (perlakuan $E)$ dan berbeda nyata $(P<0,05)$ dengan perlakuan $A, B$, dan C

Semakin tinggi kandungan kitin dalam pakan maka tingkat konsumsi pakan semakin menurun. $\mathrm{Ha}$ ini terjadi karena efisiensi pemanfaatan pakan dari karbohidrat sebagai sumber energi, sehingga sumber energi dari protein dan lemak bisa disimpan sebagai cadangan pertumbuhan. Kondisi ini memberikan indikasi bahwa efisiensi pemanfaatan pakan pada

Tabel 2. Laju pertumbuhan harian gurami setiap perlakuan selama penelitian (30 hari)

Table 2. Daily growth rate of gouramy of each treatment during the experiment (30 days).

\begin{tabular}{|c|c|c|c|c|}
\hline \multirow{2}{*}{$\begin{array}{c}\text { Jumlah kitin dalam } \\
\text { pakan (\%) } \\
\text { Chitin content in } \\
\text { diet (\%) }\end{array}$} & \multicolumn{4}{|c|}{ Ulangan (Replication) } \\
\hline & 1 & 2 & 3 & $\begin{array}{l}\text { rata-rata } \\
\text { average }\end{array}$ \\
\hline 0 & 2.07 & 2.15 & 1.93 & $2.05 \pm 0.11^{a}$ \\
\hline 4 & 2.40 & 2.15 & 2.11 & $2.19 \pm 0.16^{a}$ \\
\hline 8 & 2.46 & 2.86 & 2.50 & $2.61 \pm 0.22^{b}$ \\
\hline 12 & 2.78 & 2.49 & 2.58 & $2.59 \pm 0.18^{\mathrm{b}}$ \\
\hline 16 & 2.53 & 2.61 & 2.59 & $2.54 \pm 0.14^{b}$ \\
\hline
\end{tabular}

Angka dalam kolom yang diikuti huruf superskrip yang sama tidak berbeda nyata Values in columns followed with the same superscript are not significantly $(P>5.0)$

Tabel 3. Laju konsumsi pakan harian gurami setiap perlakuan selama penelitian (30 hari).

Table 3. Daily consumption rate of gouramy of each treatment during the experiment (30 days)

\begin{tabular}{|c|c|c|c|c|}
\hline \multirow{2}{*}{$\begin{array}{c}\text { Jumlah kitin dalam } \\
\text { pakan (\%) } \\
\text { Chitin content in } \\
\text { diet }(\%)\end{array}$} & \multicolumn{4}{|c|}{ Ulangan (Replication) } \\
\hline & 1 & 2 & 3 & $\begin{array}{l}\text { rata-rata } \\
\text { average }\end{array}$ \\
\hline 0 & 2.43 & 2.45 & 2.31 & $2.41 \pm 0.04^{a}$ \\
\hline 4 & 2.40 & 2.37 & 2.40 & $2.39 \pm 0.02^{a}$ \\
\hline 6 & 2.35 & 2.31 & 2.28 & $2.31 \pm 0.05^{b}$ \\
\hline 12 & 2.29 & 2.22 & 2.27 & $2.26 \pm 0.04^{b c}$ \\
\hline 16 & 2.20 & 2.20 & 2.24 & $2.21 \pm 0.12^{c}$ \\
\hline
\end{tabular}

Angka dalam kolom yang diikuti huruf superskrip yang sama tidak berbeda nyata Values in columns followed with the same superscript are not significantly $(P>5.0)$ 
ikan yang menerima pakan tanpa kitin lebih rendah dibandingkan jika diberikan pakan dengan sumber kitin. Hal ini didukung dari hasil perhitungan konversi pakan yaitu semakin tinggi kandungan kitin yang diberikan maka konversi pakan semakin menurun (Tabel 4). Konversi pakan pada perlakuan A dan B tidak berbeda nyata $(P>0,05)$. Konversi pakan pada perlakuan C, D dan E semakin menurun dan di antara ketiga perlakuan tersebut tidak berbeda $(P>0,05)$, namun berbeda terhadap perlakuan $A$ dan $B$.
Departemen Pendidikan dan Kebudayaan yang telah memberikan kesempatan dan dana untuk melaksanakan penelitian ini.

\section{DAFTAR PUSTAKA}

Clark, D.J., A.L. Kawrence and D.H.D. Swakon 1993 Apparent chitin digestibility in penaeid shrimp. Aquaculture, 109:51-57

\begin{tabular}{|c|c|c|c|c|}
\hline \multirow{2}{*}{$\begin{array}{c}\text { Jumlah kitin dalam } \\
\text { pakan (\%) } \\
\text { Chitin content in } \\
\text { diet }(\%)\end{array}$} & \multicolumn{4}{|c|}{ Ulangan (Replication) } \\
\hline & 1 & 2 & 3 & $\begin{array}{l}\text { rata-rata } \\
\text { average }\end{array}$ \\
\hline 0 & 2.43 & 2.45 & 2.31 & $1.16 \pm 0.06^{a}$ \\
\hline 4 & 2.40 & 2.37 & 2.40 & $1.07 \pm 0.02^{a}$ \\
\hline 6 & 2.35 & 2.31 & 2.28 & $0.88 \pm 0.07^{b}$ \\
\hline 12 & 2.29 & 2.22 & 2.27 & $0.88 \pm 0.05^{b}$ \\
\hline 16 & 2.20 & 2.20 & 2.24 & $0.84 \pm 0$ \\
\hline
\end{tabular}

Angka dalam kolom yang diikuti huruf superskrip yang sama tidak berbeda nyata Values in columns followed with the same superscript are not significantly $(P>5.0)$

Dari hasil tersebut dapat diduga bahwa kitin dapat membantu dalam mencerna pakan sehingga menjadi nutrien yang mudah diserap oleh ikan. Diduga bahwa kitin berperan dalam metabolisme karbohidrat pada ikan gurami. Hasil penguraian kitin berupa $\mathrm{N}$-asetilglukosamin berfungsi sebagai pemacu pertumbuhan (Lynn, 1990; Spindler-Bath et al., 1990). Dengan meningkatnya daya cerna karbohidrat dan lemak menyebabkan kemungkinan adanya penukaran penggunaan protein sebagai sumber energi, pengurangan proses termogenesis oleh pakan, menurunnya kebutuhan kalori untuk produksi dan ekskresi nitrogen (Machiels \& Henken, 1985; Machiels, 1987).

\section{KESIMPULAN}

Penambahan kitin ke dalam pakan ikan dapat mempengaruhi respon pertumbuhan dan efisiensi pemanfaatan pakannya. Penambahan kitin ke dalam pakan sebesar 8,0\% dapat menghasilkan respon pertumbuhan dan pemanfaatan pakan yang lebih tinggi.

\section{UCAPAN TERIMA KASIH}

Tim Peneliti menyampaikan terima kasin kepada Agricultural Research Management Project (ARMPII) dan Direktorat Jenderal Pendidikan Tinggi (DIKTI)
Fox, C.J. 1993. The effect of dietary chitin on growth. survival and chitinase levels in the digestive gland of juvenile Penaeus monodon. Aquaculture, 109:39-49

Kanazawa, A., M. Shimaya, M. Kawasaki and K Kashiwada. 1970. Nutritional requirements of prawn, I. feeding on artificial diet. Bull. Jap. Soc. Sci. Fish. 36:949-954

Kitabayashi, K., H. Kurata., K. Shudo, K. Nakamura and S. Ishikawa. 1971. Studies on formula feed for kuruma prawn. I. On relationship among glucosamine phosphorus and calsium. Bull. Tokai Reg. Fish. Res. Lab 65:91-207.

Knorr, D. 1982. Functional properties of chitin and chitosan. J. Food Sci. and Technol. Vol. 47:593

Lynn, K.R. 1990. Chitinases and Chitobiases from the American lobster (Homarus americanus). Comp. Biochem. Physiol., 96B:761-766.

Machiels, M. and A. Henken. 1985. Growth rate, feed utilization and energy metabolism of the African catfish (Clarias gariepinus), as affected by dietary protein and energy content. Aquaculture 44:271-284

Machiels, M.A.M. 1987. A. Dynamic simulation model for growth of the African catfish, Clarias gariepinus (Burchell 1822): IV. The effect of feed formulation on growth and feed utilization. Aquaculture, 64:305-323.

Muzzarelli, R.A.A. 1977. Chitin. Pergamon Press. New York.

NRC. 1983. Nutrient Requirement of Warm Water Fishes. Washington D.C., National Academy of Sciences. 
Snedecor, G. and W. Cochran, 1991. Statistical methods, 8th edition, lowa State University Press, lowa, USA. $499 \mathrm{pp}$

Suhadi, U. Santoso, S. Angrahini, Nurcahyanto. 1993. Buku Monograf Khitin dan Khitosan. PAU. Pangan dan Gizi. UGM, Yogyakarta
Spindler-Bath. M., A. Van Wormhoundt, \& K.D. Spindler 1990. Chitinolytic enzymesin the integument and midgut-gland of the shrimp Palaemon serratus during the moulting cycle. Mar, Biol., 106:49-52. 